\title{
PAGALBOS VAIKUI YPATUMAI PO JO ATSKYRIMO NUO BIOLOGINĖS ŠEIMOS
}

\author{
Žydra Kuprẻnaitė, Jolita Lubienė, Deimantė Dikovičiūtè \\ Utenos kolegijos Medicinos fakultetas
}

Raktažodžiai: vaikas, vaiko gerovè, biologinè šeima, vaiko teisių apsaugos sistema, socialinis darbuotojas, atvejo vadybininkas.

\begin{abstract}
Santrauka
Paskutiniu metu vaikų gerovès užtikrinimo problemos yra aktyviai aptariamos ir analizuojamos Lietuvos vaiko teisių apsaugos sistemoje. Siekiama sukurti tokią vaiko teisių apsaugos sistemą, kuri užtikrintų ir gintų vaiko teises ir teisètus interesus, tinkamu laiku reaguotų i pažeidimus, operatyviai priimtų sprendimus. Ne visada tévai gali sudaryti tinkamas sąlygas augantiems vaikams. Vaikas iš tèvų gali būti paimtas dèl tokių priežasčių: vaikas auga nesaugioje aplinkoje, kurioje gali grèsti pavojus jo sveikatai bei gyvybei; vaikas paliktas be priežiūros arba su netinkamais asmenimis; vaiko tèvai (arba vienas turimas) yra dingę; tèvai laikinai, pvz., dèl ligos, negali rūpintis vaiku.
\end{abstract}

\section{Ivadas}

Kai kyla pavojus vaiko gerovei, sveikatai ar gyvybei, jis paimamas iš šeimos, tačiau tikrai nebūtinai atsiduria globos namuose ir yra atiduodamas ịvaikinti. Pirmiausia vaikai apgyvendinami giminaičių ar asmenų, susijusių su vaikais artimais ryšiais, šeimose; jeigu tokių asmenų neatsiranda, vaikas apgyvendinamas budinčių globotojų šeimoje.

Iš viso $2019 \mathrm{~m}$. globos centruose dirbo apie 400 darbuotojų, tarp jų - psichologai, globos koordinatoriai bei atestuoti specialistai, vedantys globejų (rūpintojų), budinčių globotojų, ịtėvių, bendruomeninių vaikų globos namų darbuotojų mokymus. Remiantis 2019 m. gruodžio mėnesio duomenimis, Lietuvoje iš viso tèvų globos yra netekę 7,4 tūkst. vaikų; iš jų apie 1,4 tūkst. nustatyta laikinoji, o apie 6 tūkst. - nuolatinè globa. Pagal turimą statistiką, 4,8 tūkst. vaikų Lietuvoje yra globojama šeimose, 360 vaikų - šeimynose, 1,9 tūkst. - globos institucijose (iš jų apie 500 gyvena bendruomeniniuose globos namuose) ir dar apie 250 vaiku prižiūri budintys globotojai [12].
Galima teigti, kad 2017 m. buvo sisteminių pokyčių vaiko gerovès srityje metai: Lietuvos Respublikos Seimas 2017 m. rugsèjo 28 d. prièmė Vaiko teisių apsaugos pagrindų ìstatymo Nr. I-1234 pakeitimo ịstatymą, kuris įsigaliojo 2018 m. liepos $1 \mathrm{~d}$. Šio įstatymo tikslas - užtikrinti vaiko teisių apsaugą, nustatant vaiko teisių apsaugos sistemos reglamentavimą $[1,5]$.

Pastebètina, kad nuo 2018 m. liepos 1 d. iki 2019 m. sausio 31 d. Lietuvoje užfiksuoti 795 atvejai, kai buvo nustatytas antrasis grèsmès lygis ir įvykdytas vaikų atemimas iš jų tėvų šeimų. Konkrečiai Utenos rajono savivaldybeje per tą pati laikotarpi buvo užfiksuota 11 vaikų atėmimo atvejų $[3,10]$.

Remiantis Lietuvos vaiko teisių apsaugos ir ịvaikinimo tarnybos prie Socialinès apsaugos ir darbo ministerijos pateikiamais duomenimis, ịsigaliojus vaiko globos ịstatymo pokyčiams nuo $2018 \mathrm{~m}$. liepos 1 d. iki $2019 \mathrm{~m}$. vasario $28 \mathrm{~d}$., didžiausias skaičius atvejų, kai buvo gautas pranešimas dèl grèsmès vaikui ir vertintas grèsmès vaikui lygis, pastebimas spalio mènesị (2839). Tačiau, aptariant tuos pačius spalio mènesio duomenis, pastebètina, kad net 1378 atvejais grèsmès vaikui lygis buvo vertintas, bet grèsmė nenustatyta. Iš minètų 2839 atvejų, fiksuotų spalio mènesị, pirmasis grèsmès lygis (vaiko teisių pažeidimai) nustatytas 1262 atvejais. Antrasis grèsmès vaikui lygis, kai vaikas buvo paimtas iš jo atstovu pagal įstatymą (nustatytas realus povojus vaiko saugumui, sveikatai ar gyvybei) patvirtintas 199 atvejais. Šie duomenys leidžia teigti, kad įstatymo pakeitimai ypač suaktyvina visuomenès dèmesi galimiems vaiko teisès pažeidimams, tačiau, remiantis tokiu dideliu kiekiu atvejų, kai grèsmè visgi nenustatyta, galima įžvelgti įstatymo veiksmingumo spragas $[8,11]$.

Vaiko teise gyventi drauge su biologiniais tèvais, būti auklëjamam ir aprūpintam tèvų šeimoje išplaukia iš kiekvieno žmogaus prigimties. Tačiau nèra ir negali būti prievartos priemonių bei mechanizmo, kuris padètų užtikrinti šių vaiko teisių igyvendinimą. Dèl šios priežasties tais atvejais, kai tèvai negali ar nenori užtikrinti minètų vaiko teisių, prievolès imasi valstybè. Pirmiausia valstybè, remdamasi teisinio reguliavimo priemonėmis, užtikrina globos steigimą kie- 
kvienam vaikui, kuris yra likęs be tėvų globos. Tačiau labai svarbu atkreipti dèmesị i tai, kad valstybè, prisiimdama vaiko globą ir aktyviai siekdama sukurti tinkamas sąlygas globos ìstaigose, nepažeistų svarbiausio vaiko globos organizavimo principo - vaiko interesu pirmumo $[6,9]$.

Tyrimo tikslas - atskleisti pagalbos, specialistų teikiamos vaikui po jo atskyrimo nuo biologinès šeimos, pobūdį.

\section{Tyrimo objektas ir metodika}

Tyrimo objektas. Pagalbos vaikui ypatumai po jo atskyrimo nuo biologinès šeimos.

Tyrimas vyko 2019 m. vasario-gegužès mèn., respondentai atrinkti, taikant tikslinę atranką, buvo apklausti socialiniai darbuotojai ir socialinio darbo specialistai, generalinè imtis -30 , imties tūris -28 , taikytas kiekybinis tyrimo metodas anketinè apklausa, tyrimo instrumentą sudare 30 klausimų. Iš viso išdalinta 30 anketų, iš jų 28 grąžintos užpildytos. Dalis anketų (18) buvo išdalinta $X$ socialinių paslaugų centre, kita dalis (12) anketu $-X$ šeimos ir vaiko gerovès centre, likusios (3) - $X$ vaikų ir jaunimo užimtumo centre. Sprendžiant tyrimo etikos klausimus, gauti leidimai atlikti tyrimą, prieš tai supažindinus tirtų institucijų administratorius su tyrimo

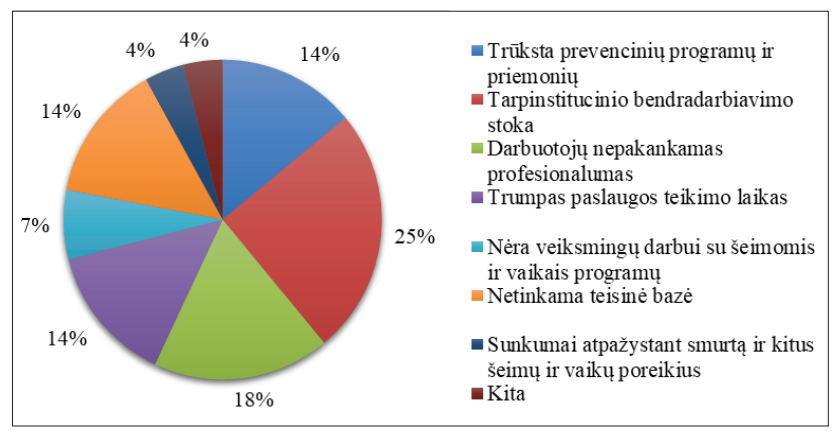

1 pav. Respondentų atsakymų apie jų įžvelgiamas svarbiausias problemas, kylančias teikiant pagalbą šeimoms po vaiko atskyrimo, pasiskirstymas

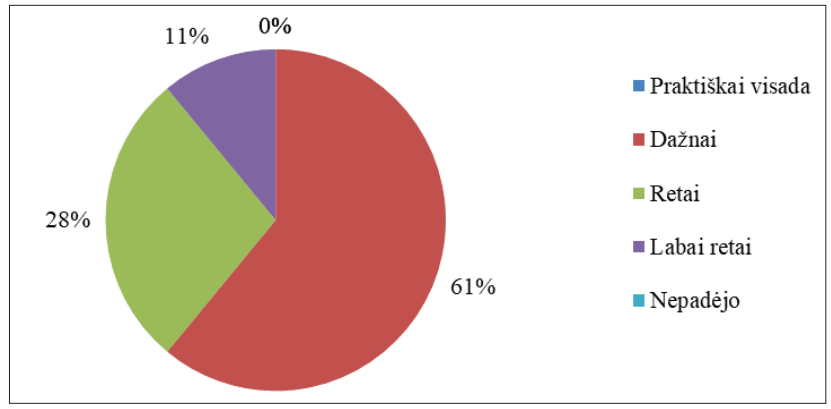

2 pav. Respondentų atsakymų, kaip dažnai veiksminga jų teikiama socialinè pagalba šeimoms, sprendžiant po vaiko atskyrimo kylančias problemas, pasiskirstymas procedūra bei instrumentu. Gauti duomenys apdoroti, naudojantis Microsoft Office Excel kompiuterine programa, rezultatai pateikiami procentine išraiška sektorinèse diagramose.

\section{Tyrimo rezultatai ir ju aptarimas}

Kaip parode gauti rezultatai, tyrime dalyvavusieji yra vyresnio amžiaus socialiniai darbuotojai ir socialinio darbo specialistai: 54 proc. iš jų yra $45-50 \mathrm{~m}$., 21 proc. $-35-40$ $\mathrm{m}$., 14 proc. $-50 \mathrm{~m}$. ir vyresni, 11 proc. $-30-35 \mathrm{~m}$. amžiaus. Iš viso 57 proc. respondentų turi aukštajį universitetinį, 39 proc. - aukštajj neuniversitetinị išsilavinimą, o 4 proc. apklaustų darbuotojų dar tik studijuoja socialinị darbą. Pagal darbo stažą respondentai pasiskirste taip: 64 proc. iš jų darbo stažas $-10-15 \mathrm{~m} ., 11$ proc. $-3-5 \mathrm{~m} ., 11$ proc. $-6-10 \mathrm{~m}$., taip pat 11 proc. nurodè, kad jų socialinio darbo stažas yra daugiau nei 15 metų, ir tik 3 proc. respondentų turi 1-2 m. darbo stažą.

Tyrimo metu, paklausus respondentų, kokias problemas jie įžvelgia, teikdami pagalbą šeimoms po vaiko atskyrimo (1 pav.), paaiškejjo, kad svarbiausia problema - tarpinstitucinio bendradarbiavimo stoka ( 25 proc.) bei nepakankamas darbuotojų profesionalumas (18 proc.). Tarpinstitucinis bendradarbiavimas nepakankamas, nes institucijos tarpusavyje nederina politinių sprendimų, dubliuoja vienos kitų veiklas, netęsia pradètų darbų ir pan. Vienas iš tinkamiausių metodų šiai problemai spręsti yra tarpinstitucinio bendradarbiavimo

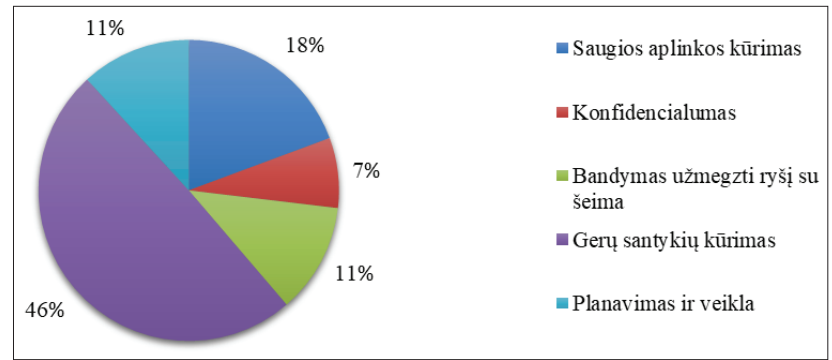

3 pav. Respondentų atsakymų apie svarbiausius iššūkius, kylančius dirbant su šeima, iš kurios buvo paimti vaikas (-ai), pasiskirstymas

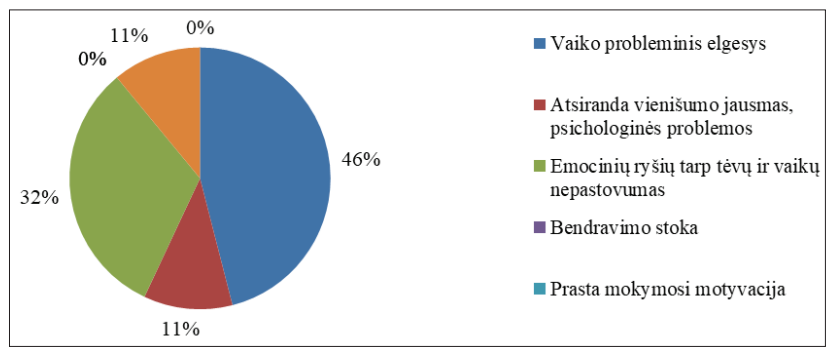

4 pav. Respondentų atsakymų apie dažniausiai vaikui (-ams), atskirtam (-iems) nuo biologinių tėvų kylančiomis problemomis, pasiskirstymas 


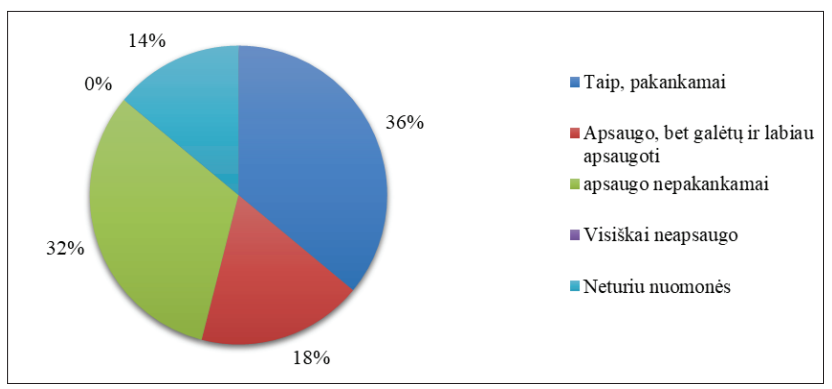

5 pav. Respondentų atsakymų, kiek pakankama vaikų iš šeimų, patiriančių socialinę riziką, apsauga pagal Lietuvoje galiojančius ìstatymus, pasiskirstymas

stiprinimas, dèl kurio turi keistis darbo su šeima turinys bei formos, grindžiamos naujais tarpusavio santykiais. İžvelgiant darbuotojų profesionalumo stoką, pastebètina, kad sparti reformų kaita vaiko teisių apsaugos srityje ir dideli darbo krūviai gali daryti ịtakos specialistų pasirengimui, profesionaliai sprendžiant problemas, kylančias dèl vaiko atskyrimo nuo šeimos.

Duomenys, gauti atlikus tyrimą, parodè, kad, nors ir kyla problemų, sprendžiant iššūkius, susijusius su vaiko atskyrimu nuo biologinès šeimos, tačiau, kaip teigia didžioji dalis (61 proc.) respondentų, jiems teikiant socialinę pagalbą, dažnai išsprendžiamos šeimos problemos, atsirandančios po vaiko atskyrimo (2 pav.).

Paklausus respondentų, kas svarbiausia, dirbant su šeima, iš kurios buvo paimtas vaikas (-ai), paaiškèjo, kad ypač reikšmingas yra gerų tarpusavio santykių kūrimas (46 proc.) ir saugios aplinkos užtikrinimas (18 proc.) (3 pav.). Emocinè parama (užuojauta, išsikalbejjimas, supratimas, išklausymas) ypač reikalinga, kaip viena iš pagalbos rūšių socialinę riziką patiriančiai šeimai, iš kurios paimti vaikai. Riziką patiriančiu šeimų gyvenimo problemiškumą iš dalies didina nepagrịstas nusiteikimas prieš jas.

Atliekant tyrimą, išsiaiškinta, su kokiais iššūkiais dažniausiai susiduria vaikas (-ai), atskirtas (-i) nuo biologinių tèvų: aktualiausias - problemiškas vaikų elgesys (46 proc.), taip pat svarbi problema yra emocinių ryšių tarp vaikų ir tèvų nepastovumas (32 proc.) bei vienišumo jausmas ir psichologinès problemos (11 proc.) (4 pav.). Vaikas, atskirtas nuo biologinių tèvų, patiria traumą, dèl kurios jis jaučiasi bejègis. Svarbu analizuoti nuo biologinès šeimos atskiriamo vaiko socialinių santykių su jo tèvais ar kitais artimais giminaičiais kokybę, pastovumą, tvirtumą. Vaiko socialiniai ryšiai - tai jo santykiai su pirminiu socialiniu tinklu. Atskirto nuo šeimos vaiko bendravimas su biologiniais tèvais - sudetingas klausimas darbuotojams, kurie tiesiogiai dirba su šiais vaikais, siekdami užtikrinti jiems saugią aplinką bei palankų emocinį ir psichologinị mikroklimatą.

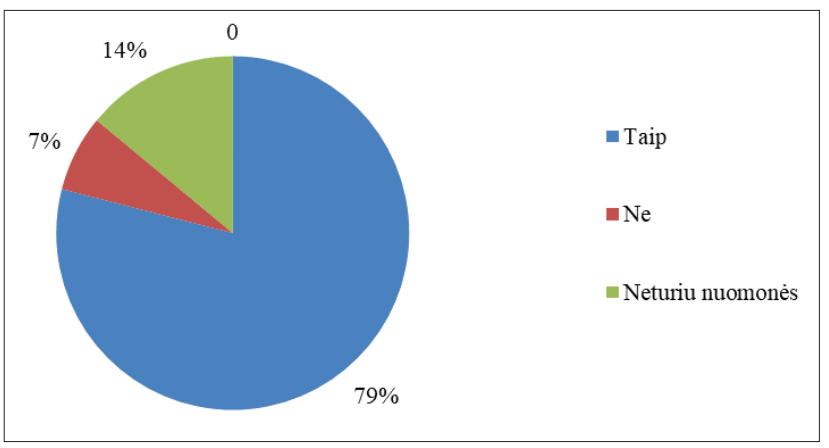

6 pav. Respondentų atsakymų, ar pasiteisino nuo 2018 m. liepos 1 d. ịsigalioję Vaiko teisių apsaugos įstatymo pakeitimai, pasiskirstymas

Dalies respondentų teigimu (36 proc.), galiojantys įstatymai pakankamai apsaugo šeimų, kurios patiria socialinę riziką, vaikus, trečdalio apklaustujų manymu (32 proc.) teisinè apsauga nepakankama (5 pav.).

Pasak didžiosios dalies respondentų (79 proc.), $2018 \mathrm{~m}$. liepos 1 d. atlikti Vaiko teisių apsaugos įstatymo pakeitimai pasiteisino - efektyviau ginamos vaikų teisès, nepaneigiant kiekvieno vaiko prigimtinès teisès augti biologineje šeimoje. Vaiko paèmimas iš tèvų įmanomas tik tuomet, jeigu, nustačius vaiko apsaugos poreikị ir pritaikius laikinają priežiūrą bei suteikus pagalbą, situacija nesikeičia arba blogeja, o tėvai nenori keisti savo elgesio. Taip pat po įstatymo pakeitimų suteikiama veiksmingesnè ir operatyvesnè pagalba šeimoms, ịvairios tarnybos gali susitelkti, reaguodamos ị konkrečius atvejus bei spręsdamos konfliktines situacijas.

\section{Išvados}

1. Atlikus pokyčiu vaiko globos (rūpybos) sistemoje apžvalgą, galima teigti, kad pagrindinis pokyčių vaiko globos sistemoje tikslas - užtikrinti vaiko teisę ramiai augti saugioje aplinkoje, megzti tvirtus ryšius naujojoje šeimoje. Nuo 2018 m. liepos 1 d. teismo leidimu vaikui skirtas globèjas ar nustatytas tėvų valdžios apribojimas leidžia užtikrinti saugesnes sąlygas vaikui augti, kol bus išspręstos problemos globos institucijoje ar šeimoje. Sukurta vaiko teisių apsaugos sistema užtikrina bei gina vaiko teises ir teisetus interesus, tinkamu laiku reaguoja ị pažeidimus ir operatyviai priima sprendimus.

2. Ištyrus pagalbos ypatumus po vaiko atskyrimo nuo biologinès šeimos, paaiškèjo, kad darbe su šeima, iš kurios buvo paimtas (-i) vaikas (-ai), svarbiausia - gerų santykių kūrimas tarp vaiko ir biologinių tèvų. Dèl didelio darbo krūvio specialistams nebelieka laiko tinkamai atlikti darbą, o kartais pritrūksta ir motyvacijos. Kai teikiama pagalba šeimoms po vaiko atskyrimo, labai svarbus tarpinstitucinis bendradarbiavimas ir profesinis pasirengimas. 
3. Remiantis tyrimo rezultatais, galima pateikti tokias praktines rekomendacijas: siekti, kad specialistų, teikiančiu socialinès priežiūros paslaugas šeimoms, patiriančioms riziką, laikas, skiriamas pildyti dokumentus, užimtų kuo mažiau viso darbo laiko; vienai pareigybei priskirti ne daugiau nei 10 šeimų, patiriančių socialinę riziką.

\section{Literatūra}

1. Ankstyvosios intervencijos modelis ir jo igyvendinimo Lietuvos savivaldybėse schemos (dokumentų paketas).

2. Bučiūnas G., Velička V. Keitimasis informacija ir tarpinstitucinis bendradarbiavimas tiriant smurto artimoje aplinkoje atvejus. Visuomenès saugumas ir viešoji tvarka, 2017;18:165-183.

3. Buzaitytè-Kašalynienè J., Liaudginaitė-Zamalienė E. Vaikų dienos centrų tarpdalykinio bendradarbiavimo patirtis. Socialinè teorija, empirija, politika ir praktika, 2012;6:7-22.

https://doi.org/10.15388/STEPP.2012.0.1862

4. Dèl vaikų, likusių be tèvų globos, apsaugos (Rekomendacijos). Parengta pagal Jungtinių Tautų gairių projektą ir Tarptautinès Socialinès Tarnybos informacinius biuletenius. Prieiga internetu: http://vaikoteises.lt/media/file/ISS\%20gaires.pdf (žiūrèta: 2019-09-04)

5. Dikovičiūtè D. Socialinio darbuotojo pagalbos ypatumai po vaiko atskyrimo nuo biologinès šeimos (baigiamasis darbas). Utena: Utenos kolegija, 2019.

6. Kauneckienė D. Vaikų, kuriems skirta laikinoji globa, bendravimo su biologiniais tèvais plètojimas (magistro darbas). Šiauliai: ŠU, 2014.

7. Koriznaitè J. Visuomenès požiūris ị vaiko grąžinimą socialinès rizikos šeimai (magistro darbas). Šiauliai: ŠU, 2012.

8. Vaičelienè R. Socialinių darbuotojų bendradarbiavimas, teikiant socialines paslaugas smurtą šeimoje patyrusiems vaikams (magistro baigiamasis darbas). Vilnius: LEU, 2018

9. Vitkauskas K. Vaiko globos organizavimo principu igyvendinimas Lietuvoje. Viešoji politika ir administravimas, 2010;31:136-146.

10. VTA ataskaitų skiltis. SPIS (duomenų vitrinų modelis). Prieiga internetu: http://vitrinos.spis.lt:8080/vtas.html (žiūrèta: 202001-16).

11. Statistika. Valstybès vaiko teisių apsaugos ir ịvaikinimo tarnyba prie Socialinès apsaugos ir darbo ministerijos. Prieiga internetu: http://www.vaikoteises.lt/veikla/statistika/ (žiūrèta: 2020-01-22).
12. Visa informacija apie globą, ịvaikinimą ir paslaugas - vienoje vietoje. Lietuvos Respublikos socialinès apsaugos ir darbo ministerija. Prieiga internetu: https://socmin.lrv.lt/lt/naujienos/ visa-informacija-apie-globa-ivaikinima-ir-paslaugas-vienojevietoje (žiūrèta: 2020-02-04).

\section{CHARACTERISTICS OF ASSISTANCE FOR THE CHILD AFTER HIS/HER SEPARATION FROM BIOLOGICAL FAMILY}

\section{Ž. Kuprènaitė, J. Lubienė, D. Dikovičiūtė}

Keywords: child, child welfare, biological family, child rights protection system, social worker, case manager

Summary

Recently, the issues of child welfare in Lithuania have been actively discussed and analyzed by the professionals working in the system of children's rights protection. Their aim is to create a system protecting the rights of the child; this system should safeguard and protect the rights and legitimate the interests of the children, it should be revised in due time and resolutions should be taken promptly.

Parents are not always able to ensure that their children have the proper conditions to grow up. The child may be taken away from his/her parents for the following reasons: if the child grows up in an unsafe environment in which his or her health and life may be endangered; if parents cannot take care of their child due to an illness. In 2019, there were approximately 400 employees in the care centers: psychologists, care coordinators, certified specialists who provide training for adoptive parents. According to the data gathered in Lithuania (December 2019), there are 7400 children who have lost parental care, among them about 1400 children who are in temporary custody and 6000 children who are in permanent custody. In total, 4800 children are in foster care, 360 of them live in families, 1900 children live in residential institutions (approximately 500 of them are in community foster care homes) and about 250 children are supervised by custodians on duty.

Based on the results of the study, the following practical recommendations can be made: minimizing the paperwork done by specialists who provide social care for families at risk; assigning to one social worker no more than 10 families at social risk.

Correspondence to: jolitalub@gmail.com

Gauta 2020-02-25 